\title{
Effect of the Loading Rate on the Brittle Fracture of Terfenol-D Specimens in Magnetic Field: Strain Energy Density Approach
}

\author{
M. Colussi, ${ }^{a}$ F. Berto,,${ }^{\text {b, }}$ K. Mori, ${ }^{\text {c }}$ and F. Narita ${ }^{\mathrm{d}}$ \\ ${ }^{a}$ Department of Management and Engineering, University of Padua, Vicenza, Italy \\ ${ }^{\mathrm{b}}$ Department of Engineering Design and Materials, Norwegian University of Science and Technology \\ (NTNU), Trondheim, Norway \\ ${ }^{c}$ Department of Mechanical Engineering, Ibaraki University, Hitachi, Japan \\ d Department of Material Processing, Tohoku University, Sendai, Japan \\ ${ }^{1}$ berto@gest.unipd.it
}

УДК 539.4

\section{Влияние скорости нагружения на хрупкое разрушение образцов из Терфенол-Д под воздействием магнитного поля на основе подхода плотности энергии деформации}

\author{
М. Колусси ${ }^{\mathrm{a}}$ Ф. Берто ${ }^{\sigma}$, К. Мори ${ }^{\mathrm{B}}$ Ф. Нарита ${ }^{\mathrm{r}}$ \\ a Падуанский университет, Виченца, Италия \\ ${ }^{\sigma}$ Норвежский университет естественных и технических наук, Тронхейм, Норвегия

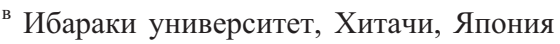 \\ г Тохоку университет, Сендай, Япония
}

Экспериментально и путем расчета оценены характерные особенности разрушения инноваичонного магнитострикционного сплава Терфенол-Д. Плоские образцы из данного материала с исходной краевой трещчиной испытывали на статический трехточечный изгиб с различныли скоростями нагружения при наличии и отсутствии магнитного поля. Исследования показывают, что для описания характеристик разрушения образцов с трешиной либо надрезом $V$ - или U-подобной формы достаточно перспективным является такой параметр, как плотность энергии деформаџии, осредненный по некоторому контрольному объему. С использованием конечноэлементного подхода проанализировано влияние магнитного поля и скорости нагружения на механизм разрушения сплава Терфенол-Д, а также возможность их учета с помощьюю критерия плотности энергии деформации. Предложена зависимость между размером контрольного объема осреднения и скоростью нагружения, а также выполнен прогноз разрушения исследуемого сплава в рамках указанного подхода.

Ключевые слова: плотность энергии деформации, скорость высвобождения энергии деформации, “интеллектуальные” материалы, сверхмагнитострикционные материалы, трещиностойкость, магнитное поле.

\section{Notation}

a $\quad-$ crack depth for cracked specimens

$\boldsymbol{B}$ - magnetic induction vector

$B_{i} \quad-i$ th component of the magnetic induction 


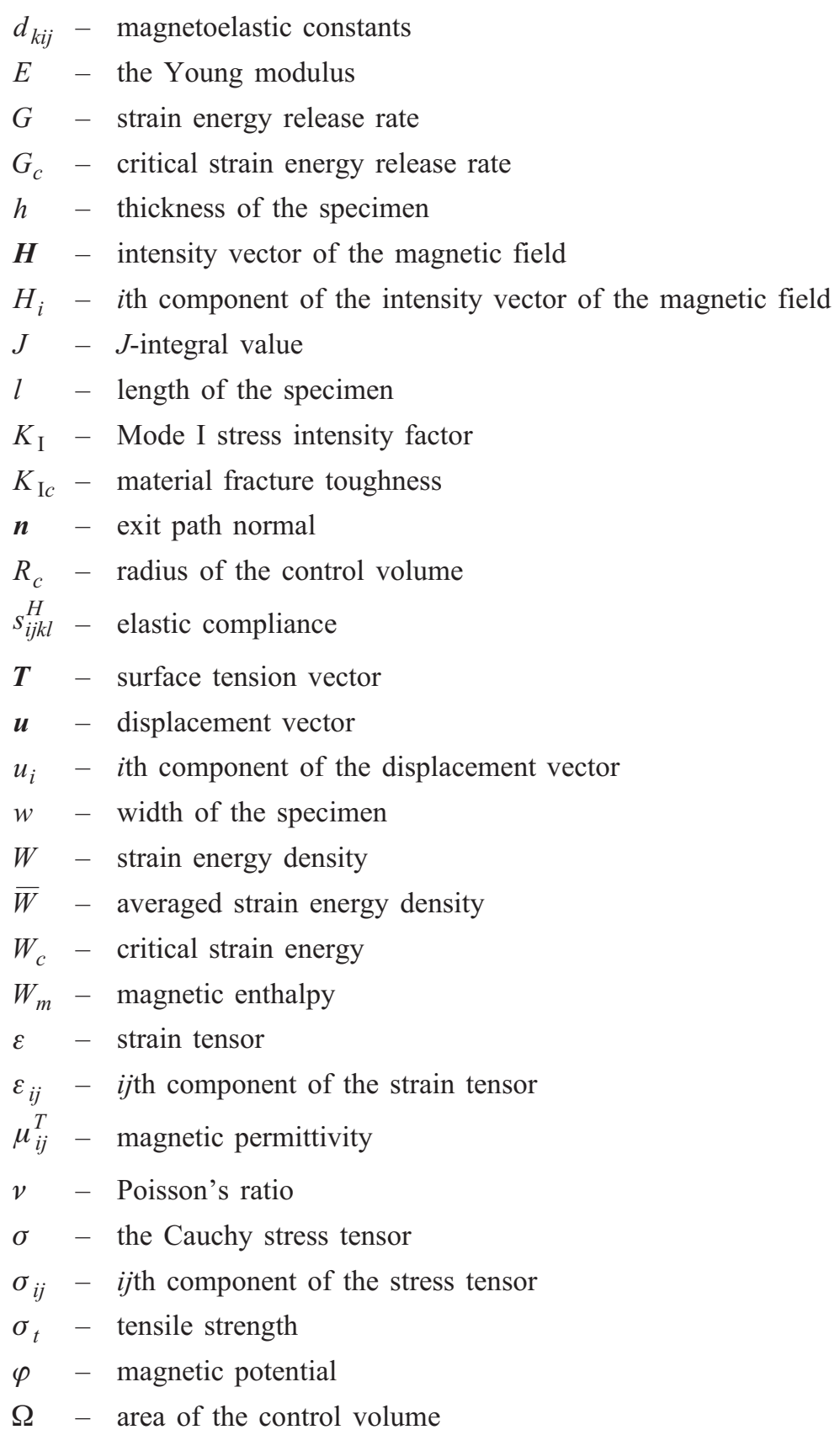

Introduction. Magnetostriction is the change in shape of materials under the influence of an external magnetic field. This effect was firstly described in the 19th century by the famous physicist James Joule. The so-called giant magnetostrictive materials exhibit a large deformation in response to external magnetic fields and a substantial magnetization changes in response to applied forces. Terfenol-D, which is a rare earth element alloy of iron, terbium, and dysprosium, is a widespread commercial material for magnetostrictive applications. This material has attracted much interest over the years, particularly because it provides one of the largest known magnetostrictive elongation and a high energy density storing capacity at room temperature, which advantages ensure a great potential in many 
applications [1]. A large field of use is in high power ultrasonic transducers. Such material is also increasingly employed in automotive industry, avionics and robotics, where magnetostriction-based actuators and sensors are commonly used [2] because of their robustness and responsiveness. A Terfenol-D-based sensor has been recently proposed for stress monitoring of steel cables in suspended bridges [3] and this material is also expected to be used in energy harvesting devices [4-6].

In spite of all these promising applications, it is well known that Terfenol-D is a brittle alloy and, as a consequence, Terfenol-D-based devices are susceptible to in-service fracture [7]. Therefore, defects caused by manufacturing and cracking can have a strong influence on the material performance. Moreover, quite a few works can be found in literature dealing with this topic, probably because Terfenol-D is a very expensive alloy, not easy to produce, both for the high reactivity of the raw materials and for the impurities contained. It is therefore of interest to gain insight into the defect sensitivity of giant magnetostrictive materials, in particular, Terfenol-D alloy.

In recent years, the strain energy density (SED) based criterion has been proposed to predict brittle failures, which occur without any plastic deformation [8]. The criterion implies that a brittle fracture occurs when the strain energy density averaged in a circular control volume, which includes a crack or notch tip, reaches the critical value, which is dependent on the material. Thereafter many researchers worked on this criterion and proved that it can successfully predict brittle and high cycle fatigue failures of cracked, U- and V-notched specimens made of several materials, including metals and ceramics [9-11]. The effect of a magnetic field on fracture behavior of Terfenol-D has recently been studied, both experimentally and numerically, by means of the energy release rate [12], and it has been shown that the material fracture resistance, under Mode I loading condition, is greater in absence of the magnetic field and decreases with the increase of the latter. It has also been proved that the resistance decrease may be related to the increase of the energy release rate with increasing magnetic fields. The extension of the SED criterion to the assessment of brittle behavior of giant magnetostrictive materials, under the same loading condition, has recently been shown in [13]. In the present work, experimental data sets on fracture behavior of Terfenol-D specimens under three-point bending have been extended and fracture loads were measured in presence and absence of the magnetic field and at different loading rates. By performing coupled-field numerical analyses the effect of the magnetic field and of the loading rate on Terfenol-D brittle failure have been discussed. The capability of the SED criterion to capture these effects has then been analyzed and, for this purpose, a relationship between the radius of the control volume and the loading rate has also been proposed.

\section{Analysis.}

1.1. Basic Equations of the Material. The basic equations for magnetostrictive materials are here outlined. Considering a Cartesian coordinate system, $x_{1}, x_{2}, x_{3}$, the equilibrium equations are given by

$$
\sigma_{j i, j}=0, \quad \varepsilon_{i j k} H_{k, j}=0, \quad B_{i, i}=0,
$$

where $\sigma_{i j}, H_{i}$, and $B_{i}$ are the components of the stress tensor, the intensity vector of the magnetic field, and the magnetic induction vector, respectively, whereas $\varepsilon_{i j k}$ is the Levi-Civita symbol. A comma followed by an index denotes partial differentiation with respect to the spatial coordinate $x_{i}$ and the Einstein summation convention for repeated tensor indices is applied.

The constitutive laws are given as

$$
\varepsilon_{i j}=s_{i j k l}^{H} \sigma_{k l}+d_{k i j} H_{k}, \quad B_{i}=d_{i k l} \sigma_{k l}+\mu_{i k}^{T} H_{k},
$$


where $\varepsilon_{i j}$ are the components of the strain tensor and $s_{i j k l}^{H}, d_{i k l}$, and $\mu_{i k}^{T}$ are the magnetic field elastic compliance, the magnetoelastic constants and the magnetic permittivity, respectively.

Valid symmetry conditions are

$$
s_{i j k l}^{H}=s_{j i k l}^{H}=s_{i j l k}^{H}=s_{k l i j}^{H}, \quad d_{k i j}=d_{k j i}, \quad \mu_{i j}^{T}=\mu_{j i}^{T} .
$$

The relation between the strain tensor and the displacement vector $u_{i}$ is

$$
\varepsilon_{i j}=\frac{1}{2}\left(u_{j, i}+u_{i, j}\right) .
$$

The magnetic field intensity, named $\varphi$ the potential, is written as

$$
H_{i}=\varphi_{, i}
$$

For Terfenol-D, the constitutive relations can be written as

$$
\begin{aligned}
& \left\{\begin{array}{l}
\varepsilon_{11} \\
\varepsilon_{22} \\
\varepsilon_{33} \\
2 \varepsilon_{23} \\
2 \varepsilon_{31} \\
2 \varepsilon_{12}
\end{array}\right\}=\left[\begin{array}{cccccc}
s_{11}^{H} & s_{12}^{H} & s_{13}^{H} & 0 & 0 & 0 \\
s_{12}^{H} & s_{11}^{H} & s_{13}^{H} & 0 & 0 & 0 \\
s_{13}^{H} & s_{13}^{H} & s_{33}^{H} & 0 & 0 & 0 \\
0 & 0 & 0 & s_{44}^{H} & 0 & 0 \\
0 & 0 & 0 & 0 & s_{44}^{H} & 0 \\
0 & 0 & 0 & 0 & 0 & s_{66}^{H}
\end{array}\right]\left\{\begin{array}{l}
\sigma_{11} \\
\sigma_{22} \\
\sigma_{33} \\
\sigma_{23} \\
\sigma_{31} \\
\sigma_{12}
\end{array}\right\}+\left[\begin{array}{ccc}
0 & 0 & d_{31} \\
0 & 0 & d_{31} \\
0 & 0 & d_{33} \\
0 & d_{15} & 0 \\
d_{15} & 0 & 0 \\
0 & 0 & 0
\end{array}\right]\left\{\begin{array}{l}
H_{1} \\
H_{2} \\
H_{3}
\end{array}\right\}, \\
& \left\{\begin{array}{l}
B_{1} \\
B_{2} \\
B_{3}
\end{array}\right\}=\left[\begin{array}{cccccc}
0 & 0 & 0 & 0 & d_{15} & 0 \\
0 & 0 & 0 & d_{15} & 0 & 0 \\
d_{31} & d_{31} & d_{33} & 0 & 0 & 0
\end{array}\right]\left\{\begin{array}{l}
\sigma_{11} \\
\sigma_{22} \\
\sigma_{33} \\
\sigma_{23} \\
\sigma_{31} \\
\sigma_{12}
\end{array}\right\}+\left[\begin{array}{ccc}
\mu_{11}^{T} & 0 & 0 \\
0 & \mu_{11}^{T} & 0 \\
0 & 0 & \mu_{33}^{T}
\end{array}\right]\left\{\begin{array}{l}
H_{1} \\
H_{2} \\
H_{3}
\end{array}\right\},
\end{aligned}
$$

where

$$
\begin{aligned}
& \left\{\begin{array}{lll}
\sigma_{23}=\sigma_{32}, & \sigma_{31}=\sigma_{13}, & \sigma_{12}=\sigma_{21}, \\
\varepsilon_{23}=\varepsilon_{32}, & \varepsilon_{31}=\varepsilon_{13}, & \varepsilon_{12}=\varepsilon_{21}
\end{array}\right. \\
& \left\{\begin{array}{lll}
s_{11}^{H}=s_{1111}^{H}=s_{2222}^{H}, & s_{12}^{H}=s_{1122}^{H}, & s_{13}^{H}=s_{1133}^{H}=s_{2233}^{H}, \\
s_{33}^{H}=s_{3333}^{H}, & s_{44}^{H}=4 s_{2323}^{H}=4 s_{3131}^{H}, & s_{66}^{H}=4 s_{1212}^{H}=2\left(s_{11}^{H}-s_{12}^{H}\right),
\end{array}\right. \\
& d_{15}=2 d_{131}=2 d_{223}, \quad d_{31}=d_{311}=d_{332}, \quad d_{33}=d_{333} .
\end{aligned}
$$

The relationship between magnetostriction and magnetic field intensity is nonlinear. The nonlinearity arises from the motion of magnetic domain walls [14]. To take into account this behavior, the constants $d_{15}, d_{31}$, and $d_{33}$ are written as a function of second-order magnetoelastic constants: 


$$
d_{15}=d_{15}^{m}, \quad d_{31}=d_{31}^{m}+m_{31} H_{z}, \quad d_{33}=d_{33}^{m}+m_{33} H_{z},
$$

where $d_{15}^{m}, d_{31}^{m}$, and $d_{33}^{m}$ are the piezomagnetic constants, whereas $m_{31}$ and $m_{33}$ are the second-order magnetoelastic constants.

1.2. Averaged Strain Energy Density Approach. According to Lazzarin and Zambardi [8], the brittle failure of a component occurs when the total strain energy, $\bar{W}$, averaged in a specific control volume located at a notch or crack tip, reaches the critical value $W_{c}$. In agreement with the Beltrami criterion [15], where $\sigma_{t}$ is the ultimate tensile strength under elastic stress field conditions and $E$ is the Young modulus of the material, the critical value of the total strain energy can be determined by the relation:

$$
W_{c}=\frac{\sigma_{t}^{2}}{2 E}
$$

The control volume takes different shapes based on the considered kind of notch. If the notch is represented by a crack, its opening angle is equal to zero and the control volume is circular and centered on the crack tip. This being the case, the radius $R_{c}$ of the control volume can be evaluated by means of the following expression [16]:

$$
R_{c}=\frac{(1+v)(5-8 v)}{4 \pi}\left(\frac{K_{\mathrm{I} c}}{\sigma_{\mathrm{t}}}\right)^{2},
$$

where $K_{\mathrm{Ic}}$ is the material fracture toughness, $v$ is Poisson's ratio, and $\sigma_{t}$ is the ultimate tensile strength of an unnotched specimen. If the material fracture toughness is unknown, an empirical approach can be a good alternative for determining $R_{c}$, as described in the following sections.

1.3. Finite Element Model. The strain energy density averaged in the control volume, $\bar{W}$, can be computed directly by means of a finite element analysis. Analyses were performed by means of ANSYS R14.5 finite element software, both in plane strain and plane stress conditions depending on the specimen width. For this purpose, solid models were used to determine the most appropriate condition. The basic equations for magnetostrictive materials are mathematically equivalent to those of the piezoelectric materials [17], so four nodes PLANE13 and eight nodes SOLID5 coupled-field solid elements from ANSYS library were used, respectively for plane and solid models, and the magnetic field has been introduced by a voltage difference. Figure 1 shows the schematic representation of the boundary conditions and the adopted reference system. The coordinate axes $x=x_{1}$ and $z=x_{3}$ are chosen such that the $y=x_{2}$ axis coincides with the thickness direction and such that the easy axis of magnetization is the $z$-direction. Because of this symmetry, only a half of the model was used.

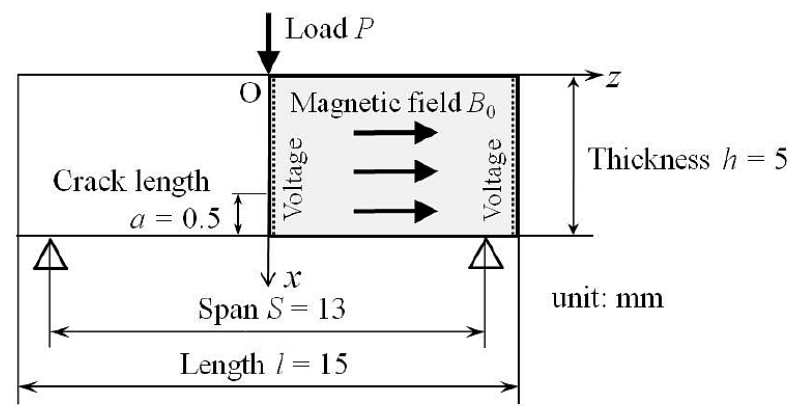

Fig. 1. Schematic representation of the model and boundary conditions. 
The mesh adopted to compute $\bar{W}$ had the same grade of refinement adopted in a previous work by the present authors [13], in which models with 6400 elements were used to evaluate the energy release rate by means of the $J$-integral for the same geometry.

2. Experimental Procedure. Among giant magnetostrictive materials, the commercially named Terfenol-D $\left(\mathrm{Tb}_{0.3} \mathrm{Dy}_{0.7} \mathrm{Fe}_{1.9}\right)$ alloy supplied by Etrema Products, Inc. (USA) was used in all tests. The material properties are listed in Table 1.

$\mathrm{T}$ a b 1 e 1

Terfenol-D Material Properties

\begin{tabular}{|c|c|c|c|c|c|c|c|c|c|c|c||}
\hline Material & \multicolumn{4}{|c|}{$\begin{array}{c}\text { Elastic compliance } \\
\left(10^{-12} \mathrm{~m}^{2} / \mathrm{N}\right)\end{array}$} & \multicolumn{2}{c|}{$\begin{array}{c}\text { Piezo-magnetic } \\
\text { constants } \\
\left(10^{-9} \mathrm{~mA}^{-1}\right)\end{array}$} & $\begin{array}{c}\text { Magnetic } \\
\text { permeability } \\
\left(10^{-6} \mathrm{H} / \mathrm{m}\right)\end{array}$ & $\begin{array}{c}\text { Density } \\
\left(\mathrm{kg} / \mathrm{m}^{3}\right)\end{array}$ \\
\cline { 2 - 12 } & $s_{11}^{H}$ & $s_{33}^{H}$ & $s_{44}^{H}$ & $s_{12}^{H}$ & $s_{13}^{H}$ & $d_{31}^{m}$ & $d_{33}^{m}$ & $d_{15}^{m}$ & $\mu_{11}^{T}$ & $\mu_{33}^{T}$ & $\rho$ \\
\hline Terfenol-D & 17.9 & 17.9 & 26.3 & -5.88 & -5.88 & -5.3 & 11 & 28 & 6.29 & 6.29 & 9250 \\
\hline
\end{tabular}

Tests were performed with the aim to measure the fracture load, $P_{c}$, of single-edge precracked specimens, subjected to three-point bending, in presence and in absence of the magnetic field and at various loading rates. The testing apparatus is reported in Fig. 2.

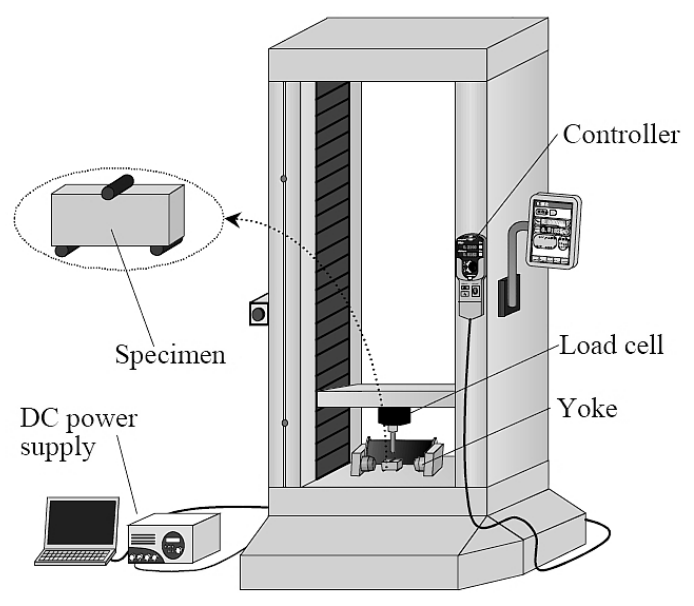

Fig. 2. Schematic representation of the experimental setup.

Specimens were $5 \mathrm{~mm}$ thick, $3 \mathrm{~mm}$ wide, and $15 \mathrm{~mm}$ long. Before testing, all specimens were weakened on one side by a $0.5 \mathrm{~mm}$ deep crack, which was introduced using a tungsten cutter. The tested specimen is shown in Fig. 3.

The load $P$ has been applied at the midpoint of the specimens, which were simply supported with span of $13 \mathrm{~mm}$, by means of a $250 \mathrm{~N}$ load cell (resolution: $0.01 \mathrm{~N}$ ). The load was applied for different loading rates: $0.05,0.5$, and $3.0 \mathrm{~N} / \mathrm{s}$. A uniform magnetic field, with magnetic induction $B_{0}$, has been applied in the longitudinal direction through an electromagnet. As devices in which Terfenol-D is employed commonly work in magnetic induction range varying from 0.02 to $0.05 \mathrm{~T}$, the representative value of $0.03 \mathrm{~T}$ has been adopted in all tests. It noteworthy that, insofar as alloying elements in Terfenol-D are terbium and dysprosium, which are very expensive rare earth elements, the number of tested specimens was limited: from two to three for each condition. 


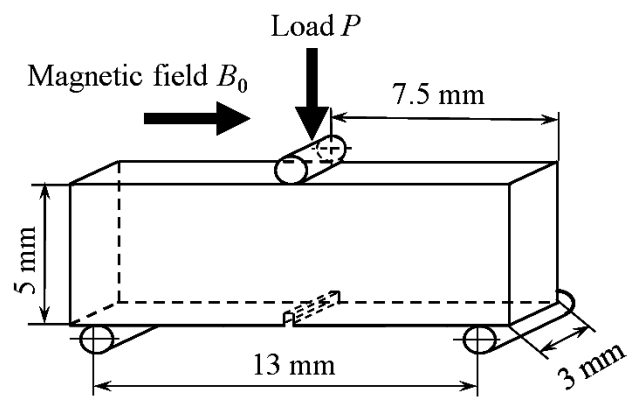

Fig. 3. Specimen geometry and testing condition.

By means of an experimental procedure it has also been possible to evaluate the nonlinear trend of Terfenol-D magnetostriction versus magnetic field intensity. Let consider a Cartesian coordinate system, $x, y, z$, whose origin is located at the top center of an uncracked specimen. Since the specimen dimension in the $z$-direction (longitudinal direction) exceeds the other two dimensions by over three times, the longitudinal magnetostriction is prevailing, and it can be assumed that $m_{31}$ is equal to zero [18]. Varying the intensity of the magnetic field applied in the $z$-direction, the trend of magnetostriction has been measured by a strain gauge located at $x=y=z=0$. By comparison between the measured strain $\varepsilon_{z z}$ and the numerically obtained one, it has been found that the proper value for the second-order magnetoelastic constant $m_{33}$ is $4.82 \cdot 10^{-12} \mathrm{~m}^{2} / \mathrm{A}^{2}$. This value has been used in the analyses to compute the SED. Figure 4 shows the trend of strain versus the applied magnetic field intensity. The full dots represent the experimental data, whereas the solid line represents the numerical trend after the second-order magnetoelastic constant has been incorporated.

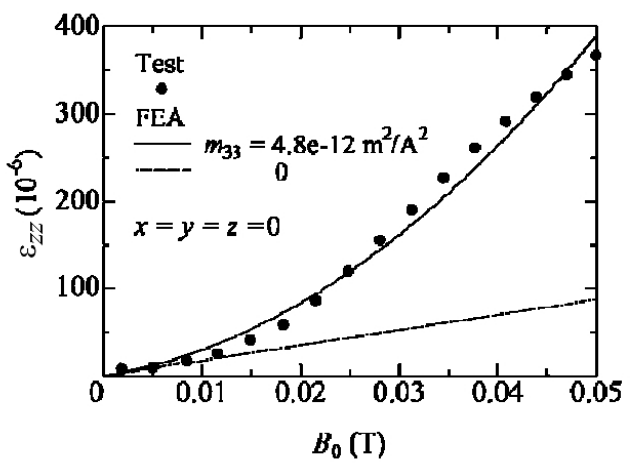

Fig. 4. Trend of strain versus magnetic field intensity in Terfenol-D.

3. Results and Discussion. Fracture loads, $P_{c}$, in presence and absence of the magnetic field have been experimentally measured at each loading rate. Data, in terms of the fracture load, are summarized in Table 2. Bold numbers represent the average values for each condition, whereas numbers in brackets indicate the relative standard deviations.

The average fracture loads are depicted in Fig. 5. The error bars indicate the maximum and minimum values of $P_{c}$. In the presence of the magnetic field, the average fracture loads at the load rates of $0.05,0.50$, and $3.0 \mathrm{~N} / \mathrm{s}$ drop by 7,9 , and $14 \%$, respectively. It has also been found that Terfenol-D exhibits the fracture load reduction as the loading rate decreases. A similar behavior has been observed for other materials, such as TiAl alloys [19] and piezoelectric ceramics [20, 21]. 


$\begin{aligned} & \text { T a } \mathrm{b} 1 \mathrm{e} 2 \\
& \text { Measured Fracture Loads as a Function of the Loading Rate and the Magnetic Field } \\
& \text { Intensity }\end{aligned}$
\begin{tabular}{|c|c|c|}
\hline \hline \multirow{2}{*}{$d P / d t}$, & \multicolumn{2}{|c|}{$P_{c}, \mathrm{~N}$} \\
$/ \mathrm{s}$ & $B_{0}=0$ & $B_{0}=0.03 \mathrm{~T}$ \\
\hline \multirow{2}{*}{0.05} & 58.3 & 59.2 \\
& 65.8 & 61.9 \\
& 74.7 & 64.6 \\
& $\mathbf{6 6 . 3}(5.81)$ & $\mathbf{6 1 . 9}(1.91)$ \\
\hline \multirow{2}{*}{0.5} & 66.6 & 60.7 \\
& 68.5 & 61.6 \\
& $\mathbf{6 7 . 5}(0.78)$ & $\mathbf{6 1 . 1}(0.37)$ \\
\hline \multirow{2}{*}{3.0} & 71.0 & 74.2 \\
& 79.2 & 59.3 \\
& - & 60.0 \\
& $\mathbf{7 5 . 1}(3.35)$ & $\mathbf{6 4 . 5}(5.95)$ \\
\hline
\end{tabular}

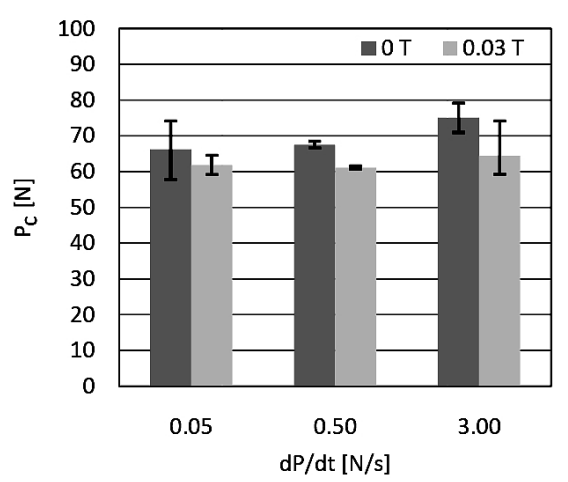

Fig. 5. Mean fracture load as a function of the loading rate and the magnetic field intensity $B_{0}$.

Since Terfenol-D material properties are loading rate-dependent, here it is assumed that the critical radius $R_{c}$, which depends on the material, varies with the loading rate. By plotting the averaged SED related to the mean values of critical loads in Table 2, in presence or absence of the magnetic field, as a function of the control volume radius, it is possible to determine different intersections for each loading rate. The intersections have been found at $0.050,0.056$, and $0.1 \mathrm{~mm}$, respectively, for the loading rates of $0.05,0.5$, and $3.0 \mathrm{~N} / \mathrm{s}$. This means that at the critical load level the material is characterized by the strain energy density averaged in the control volume having the size variable with the loading rate, which is independent of the ratio between the applied load and the magnetic field intensity. A good fit of $R_{c}$ versus loading rate to a linear model has been found by adopting a simple linear regression model. The following relationship (evaluated for the loading rates from 0.05 to $3.0 \mathrm{~N} / \mathrm{s}$ ) is proposed

$$
R_{c}=0.0195 \frac{d P}{d t}+0.05
$$

The critical radius of $0.07 \mathrm{~mm}$, obtained from (13) and proposed in [13] with no account of the loading rate, falls into the proposed variation range. 


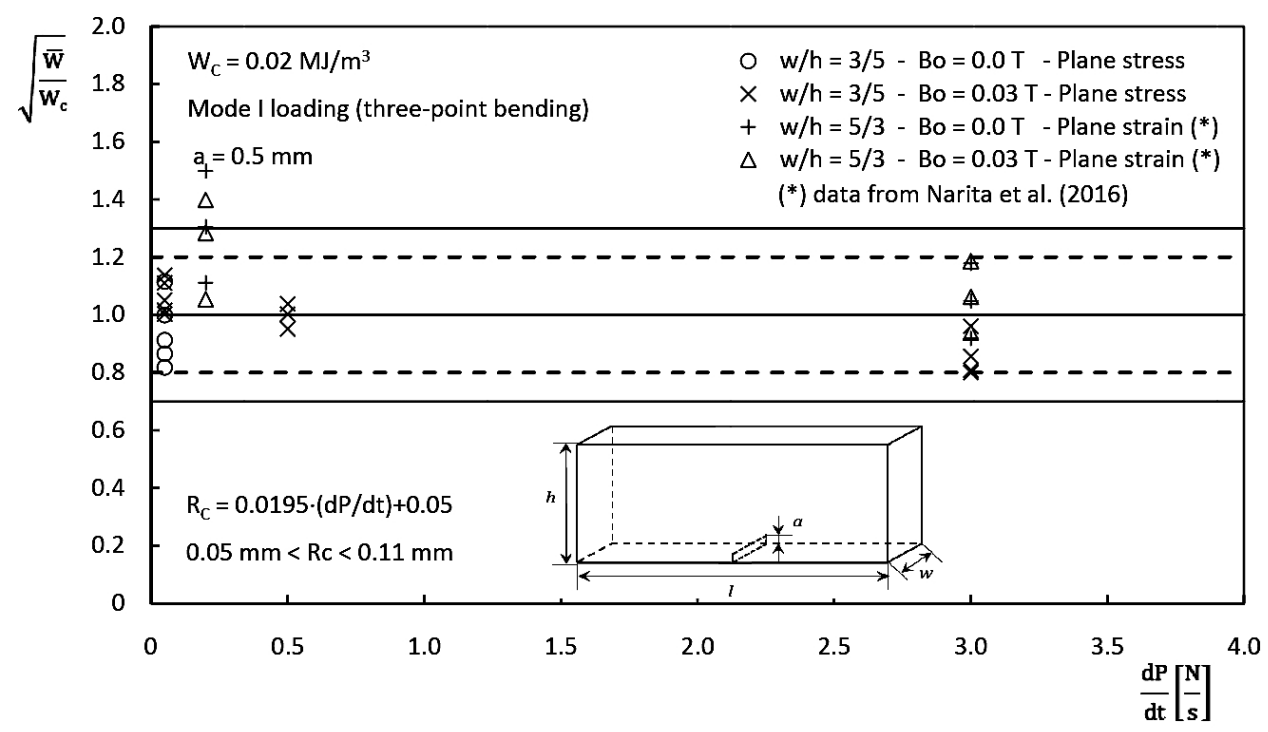

Fig. 6. Summary of results on Terfenol-D specimens with various loading rates in the presence and absence of the magnetic field $B_{0}$.

Figure 6 shows a summary of the experimental data in terms of the square root of the ratio between the averaged strain energy density, $\bar{W}$, and the critical value of strain energy, $W_{c}$. This parameter has been chosen because of its proportionality to the fracture load.

The averaged strain energy density, $\bar{W}$, has been computed in control volumes having radius given by (14), whereas a critical strain energy equal to $0.02 \mathrm{MJ} / \mathrm{m}^{3}$ is assumed. This critical value is obtained from Eq. (12), assuming the Young modulus equal to $30 \mathrm{GPa}$, Poisson's ratio equal to 0.25 , and tensile strength equal to $34 \mathrm{MPa}$, which are the medium characteristics provided by the material supplier (Etrema Products, Inc.). Here, the Young modulus is assumed to be independent from the applied magnetic field intensity. This assumption seems to be reasonable for the variation range of the applied magnetic field intensity. In Fig. 4, the experimental data from [12] have also been summarized. Data refer to fracture loads measured under three-point bending, with and without the $0.03 \mathrm{~T}$ magnetic field, at the following loading rate: 0.2 and $3.0 \mathrm{~N} / \mathrm{s}$. Specimens were $3 \mathrm{~mm}$ thick, $5 \mathrm{~mm}$ wide, and $15 \mathrm{~mm}$ long. The crack depth was $0.5 \mathrm{~mm}$. Due to the different geometry (ratio between width, $w$, and thickness, $h$, equal to $5 / 3$ instead of $3 / 5$ ) the plane strain condition instead of the plane stress condition turned out to be more appropriate for their finite element modeling. It has been found that nearly all experimental data fit in a narrow scatter band, whose limits are drawn here from 0.80 to 1.20 (4 data over 35 being outside of this range). A few data ouside this band fall, however, into the safety region of the plot. It can be concluded that the data scatter is quite limited, and the averaged SED criterion appears to be suitable for the fracture strength assessment of cracked specimens of Terfenol-D alloy under Mode I condition, in the presence or absence of the magnetic field and with variable loading rate. In the authors' opinion this is a promising result and the SED criterion seems suitable for a reliable assessment of Terfenol-D brittle failure. The proposed relationship between the size of the control volume and the loading rate also permits to take into account the loading rate by means of static finite element analyses.

Conclusions. Defect sensitivity of Terfenol-D rare earth element alloy was studied both numerically and experimentally. Under three-point bending conditions it has been found that Terfenol-D fracture resistance is greater in the absence of the magnetic field. This behavior is justified by the increase in the strain energy density around the crack tip 
when the magnetic field is acting. It has also been proven that Terfenol-D fails at decreasing fracture loads as the loading rate decreases. The averaged SED criterion captures this behavior and is able to predict Terfenol-D failures, provided a linear relationship between the size of the control volume and the loading rate is assumed.

\section{Резюме}

Експериментально і шляхом розрахунку оцінено характерні особливості руйнування іноваційного магнітострикційного сплаву Терфенол-Д. Плоскі зразки $з$ даного матеріалу з вихідною крайовою тріщиною випробовували на статичний триточковий згин iз різними швидкостями навантаження за наявності та відсутності магнітного поля. Дослідження показують, що для опису характеристик руйнування зразків із тріщиною або надрізом V- чи U-подібної форми досить перспективним є такий параметр, як щільність енергії деформації, осереднений по деякому контрольному об'єму. Із використанням скінченноелементного підходу проаналізовано вплив магнітного поля і швидкості навантаження на механізм руйнування сплаву Терфенол-Д та можливість їх урахування за допомогою критерію щільності енергії деформації. Запропоновано залежність між розміром контрольного об'єму осереднення і швидкістю навантаження та виконано прогноз руйнування досліджуваного сплаву в рамках указаного підходу.

1. G. Engdahl, Handbook of Giant Magnetostrictive Materials, Academic Press, New York (1999).

2. F. Calkins, A. B. Flatau, and M. J. Dapino, "Overview of magnetostrictive sensor technology," J. Intel. Mat. Syst. Str., 18, 1057-1066 (2007).

3. R. Zhang, Y. Duan, S. Wing Or, and Y. Zhao, "Smart elasto-magneto-electric (EME) sensors for stress monitoring of steel cables: design theory and experimental validation," Sensors, 14, 13644-13660 (2014).

4. X. Zhao and D. G. Lord, "Application of the Villari effect to electric power harvesting,” J. Appl. Phys., 99, 08M703-08M703-3 (2006).

5. P. Li, Y. Wen, P. Liu, et al., "A magnetoelectric energy harvester and management circuit for wireless sensor network," Sensor. Actuat. A - Phys., 157, 100-106 (2010).

6. K. Mori, T. Horibe, S. Ishikawa, et al., "Characteristics of vibration energy harvesting using giant magnetostrictive cantilevers with resonant tuning," Smart Mater. Struct., 24, 125032 (2015).

7. D. T. Peterson, J. D. Verhoeven, O. D. McMasters, and W. A. Spitzig, "Strength of Terfenol-D,” J. Appl. Phys., 65, 3712-3713 (1989).

8. P. Lazzarin and R. Zambardi, "A finite-volume-energy based approach to predict the static and fatigue behavior of components with sharp V-shaped notches," Int. J. Fracture, 112, 275-298 (2001).

9. F. Berto, A. Campagnolo, and P. Gallo, "Brittle failure of graphite weakened by V-notches: a review of some recent results under different loading modes," Strength Mater., 47, No. 3, 488-506 (2015).

10. F. Berto and P. Lazzarin, "Recent developments in brittle and quasi-brittle failure assessment of engineering materials by means of local approaches," Mat. Sci. Eng. R, 75, 1-48 (2014).

11. F. Berto and P. Lazzarin, "A review of the volume-based strain energy density approach applied to V-notches and welded structures," Theor. Appl. Fract. Mec., 52, 183-194 (2009). 
12. F. Narita, K. Shikanai, Y. Shindo, and K. Mori, "Three-point bending fracture behavior of cracked giant magnetostrictive materials under magnetic fields," J. Test. Eval., 44, No. 4, 1454-1460 (2015).

13. M. Colussi, F. Berto, K. Mori, and F. Narita, "Fracture behavior of cracked giant magnetostrictive materials in three-point bending under magnetic fields: strain energy density criterion," Adv. Eng. Mater., 18, No. 12, 2063-2069 (2016).

14. Y. Wan, D. Fang, and K. C. Hwang, "Non-linear constitutive relations for magnetostrictive materials," Int. J. Nonlinear Mech., 38, 1053-1065 (2003).

15. E. Beltrami, "Sulle condizioni di resistenza dei corpi elastici," Rendiconti Del Regio Istituto Lombardo, XVIII, 704-714 (1885).

16. Z. Yosibash, A. R. Bussiba, and I. Gilad, "Failure criteria for brittle elastic materials," Int. J. Fracture, 125, 307-333 (2004).

17. H. F. Tiersten, Linear Piezoelectric Plate Vibrations: Elements of the Linear Theory of Piezoelectricity and the Vibrations of Piezoelectric Plates, Springer, New York (1969).

18. Z. Jia, W. Liu, Y. Zhang, et al., "A nonlinear magnetomechanical coupling model of giant magnetostrictive thin films at low magnetic fields," Sensor. Actuat. A - Phys., 128, 158-164 (2006).

19. R. Cao, M. X. Lei, J. H. Chen, and J. Zhang, "Effects of loading rate on damage and fracture behavior of TiAl alloys," Mater. Sci. Eng. A, 465, 183-193 (2007).

20. Y. Shindo, F. Narita, K. Mori, and T. Nakamura, "Nonlinear bending response of giant magnetostrictive laminated actuators in magnetic fields," J. Mech. Mater. Struct., 4, No. 5, 941-949 (2009).

21. F. Narita, Y. Morikawa, Y. Shindo, and M. Sato, "Dynamic fatigue behavior of cracked piezoelectric ceramics in three-point bending under AC electric fields," $J$. Eur. Ceram. Soc., 32, 3759-3766 (2012). 